\title{
Llueve, llueve como en estos poemas
}

It Rains, rains as in these poems

\section{Claudia Patricia Mantilla Durán}

Magíster en Semiótica con énfasis en lenguaje y cultura

Universidad Industrial de Santander

Docente Universidad Autónoma de Bucaramanga

cmantilla9@unab.edu.co

Artículo recibido el 03 de octubre2014

Artículo aprobado el 27 de octubre 2014



Ramón Cote. Cortesía: Pastor Virviescas Gómez

La lluvia es una cosa

que sin duda sucede en el pasado

(Jorge Luis Borges)

Cuando evoco la poesía de Ramón Cote Baraibar viene a la memoria uno de sus poemas lleno de imágenes, rotundo, en el que unas cerezas heladas cortan los labios de unos niños: Granizo y cerezas, así se 
llama. También una serie de ventanas donde vemos pasar el milagro de los seres y las cosas, como en su poema Nido de las águilas donde descubrimos la dorada y misteriosa Lisboa.

Ahora que me sumerjo en su más reciente libro, Como quien dice adiós a lo perdido -verso que retoma de Eliseo Diego-, tengo la sensación de la persistente nostalgia del que contempla lo que se ha ido y no volverá. O regresará tan solo en el recuerdo bajo la forma de un poema que luche por la permanencia.

No es casual que Ramón Cote considere que el poder de la poesía consiste en capturar lo perdido, volver a darle una nueva vida a algo que estaba ya muerto, el olvido, por ejemplo, "la poesía tiene esa capacidad enorme de recuperar la cosas, estos poemas son de alguna manera poemas de recuperación”.

\section{Es otra vez octubre}

Es otra vez octubre y mi memoria

se abre al recuerdo para encontrar

ese hilo de luz remota que me lleve a esas ciudades

de la India y su cautela a la entrada

de los templos, con los pies descalzos, dejando atrás

ese polvo amarillo de sus carreteras

interminables y suicidas.

Alli estuve y sin embargo tan lejos está

ese pasado mes de octubre. El recuerdo exige

una ceremonia solitaria para lograr cierta exactitud,

para tocar ese punto cardinal

y respirar en el aire esos jazmines

que me devuelven hasta alli,

sin vanas nostalgias ni engañosos espejismos.

Si lo que fuimos es lo que somos

y si lo que nos sucede hoy será lo que seremos,

entonces le pido a las palabras que sean

sólo presente constante, transparencia pura

y encarnación de ese octubre 
de hace tan solo un año, para no separarme

jamás de la penumbra de ese atardecer donde el canto

de los pavorreales entre los árboles

retumbaba en medio de los templos destruidos

mientras la luna como un metal reciente,

sin labrar aún, anunciaba desde lo alto la llegada

de la primera noche del primer día de la creación.

En este libro siempre hay alguien que observa el trasfondo de la vida y, así como la maduración de un fruto hace que caiga por su peso, por su tiempo, la memoria en estos poemas se desgrana en un ritmo espaciado donde mirar es acariciar y reflexionar a su vez, fijar los momentos más luminosos o devastadores, todo dentro del dominio del poema que aspira a la belleza, a lo eterno.

\section{Mis muertes}

A los dieciséis años

uno de mis mejores amigos del colegio

se pegó un tiro en la cabeza

por una decepción amorosa.

A los treinta y nueve

mi más admirado profesor de literatura

murió de hipotermia en un río,

por salvar a su perro que se ahogaba

bajo una engañosa capa de hielo.

A los cuarenta y cuatro

un poeta norteamericano que acababa

de conocer desapareció para siempre

en una remota isla al sur del Japón

por ver de cerca la boca de un volcán.

Muchos dirán con sangre fría

que la impaciencia del primero,

la extrema confianza del segundo

o el imprudente proceder

del tercero, fueron la causa determinante, 
como si esas explicaciones pudieran alterar

la gravedad de los resultados.

A lo largo de la vida

uno va acumulando muertes

y se empieza a pensar sin quererlo

en cuál de esas será la suya,

si será por amor, Sergio, por lealtad,

Eduardo, o por valentía,

Craig.

Sorprende también encontrar un tono irónico porque, la ironía es una inteligencia que emociona, más aún cuando se trata de poesía. Así lo advertimos en Mis contemporáneos.

\section{Mis contemporáneos (o crisis de identidad tardía)}

Mirando la cara de mis contemporáneos

me extraña que yo aún no tenga

la cara de mis contemporáneos.

Me explico: cuando los veo en las fotografías

que aparecen en los periódicos o en las revistas

veo en ellos ya una resolución facial,

una contextura ósea, un aplomo, un cráneo definido,

pero cuando me miro no me veo así de ajustado,

de propicio, de sereno y seguro como los tiempos mandan.

Pero al parecer este nunca va a ser mi caso

pues inevitablemente siempre salgo en las fotografías

con cara de perro perdido en una autopista,

con cara de decir adiós a lo perdido,

con cara de turista extraviado en Madrás,

con cara de llamarme Patricio, Bonifacio, Agustín,

Benigno, Arturo, Carlos Mario, Ismael, si no os importa.

Nunca como mis contemporáneos.

Envidio que sus fotos se repitan y se vean

iguales o parecidos a la edad y oficio que tienen. Yo solo veo 
en mí lo que no es de mí. Es más, para ahondar en el error

no me reconozco ni a los veinte ni a los treinta ni a los cuarenta,

porque solo advierto el extravío, la carencia

o la equivocación y todos los que aparecen allí,

sobre ese pedazo de papel esmaltado, son tan distintos

que parece que se las hubieran tomado

a otra persona, a un desconocido, a Nadie.

Sé que todos se aproximan a los cincuenta y ya es hora,

me digo, de adquirir cierta rotundidad o estremecimiento,

pero no lo veo en mí fácilmente. Algo se me oculta

en el que me dice que soy. Siempre me hace falta la foto

definitiva en la que al fin pueda decirme a mí mismo

que ese soy yo, uno de mis contemporáneos,

pero tal parece que existe una conspiración

para que eso no suceda. Una fotografía, una máscara

al menos, por favor. Y pensar que ni siquiera

he podido a lo largo de estos años hacerme un retrato

con mis propias palabras pues estas, al revelarlas,

siempre salen borrosas. Eso nunca les pasa

a mis contemporáneos.

Mientras escribo estas breves líneas llueve, llueve como en estos poemas.

\section{Autorretrato de la lluvia}

Con esta lluvia que cae y que golpea la ventana

se despide octubre, elaborando una teoría

nocturna de la abundancia y de la carencia,

haciendo un balance entre lo que se escapa

y lo que se queda, mientras escribe

signos a ciegas y traza flechas que van de la angustia

al sosiego, del presente al laberinto sin salida

de la memoria, de la muerte 
a sus demoliciones, como si el vidrio fuera el tablero

de una caótica demostración matemática.

No sé por qué razón quiero que la lluvia caiga

cada vez más fuerte, con verdadera convicción,

con total contundencia. Quizá sea

porque su repetida multiplicación me oculta

en esta noche de tormenta, me protege del presente,

me borra de mañana,

quizás porque en su desorden

puedo ser también su música.

Por la ventana resbalan uno a uno

los rostros que me esperan, la cara que tendré el próximo año,

tal vez un treinta de octubre.

\section{Poemas de Ramón Cote}

\section{Para empezar el año}

Llevas dieciséis años escribiendo

al lado de la misma ventana y en todo este tiempo

has venido rasgando con tu codo la tela del sofá

que ahora cubres con un modesto paño

para que las visitas no adviertan enseguida

el daño continuo que le has hecho al mobiliario de la casa.

Dos hijas, varios libros publicados, un matrimonio

y una biblioteca, cientos de noches

y miles de cigarrillos. Así, igual que entonces,

empiezas otro año con la misma costumbre,

considerando la posibilidad de llamar al tapicero

pero en ningún momento de cambiar de lugar 
ni mucho menos de oficio.

Algo de todo esto habrá que valga la pena,

piensas, ya de noche, con un vaso en la mano repleto de hielo

al lado de esa ventana que te ha visto tantos años

hacer lo mismo en soledad, sin molestar

a los vecinos, escuchando las notas del piano

de las variaciones Goldberg -gran Glenn Gould-,

lector de cuello inclinado, fantasma entre el humo,

silencioso suicida.

\section{La ciudad de los puentes amarillos}

Cuando llegas a tu casa por la noche

tienes por costumbre buscar esas monedas

que se han ido acumulando al fondo de los bolsillos

para armar con ellas mínimas torres

o altas columnas, según el día.

Quien desde la ventana de enfrente te vea

podría decir que pareces un mendigo

o un vulgar avaro que reúne con codicia

sus posesiones, aunque este no sea tu caso

y aunque a primera vista lo parezca.

Pero esas monedas de distintos tamaños y variadas

denominaciones son restos, gastados

testimonios que entregas y recibes diariamente,

y sin que tú mismo lo sepas alguien los va anotando

en su enorme libro de contabilidad,

para saber exactamente el precio que pagas

por cruzar esa ciudad de los puentes amarillos. 


\section{Desencuentro}

Si mi vida hubiera ido

a otra velocidad

y el tiempo me hubiera regalado diez años menos,

y si al mismo tiempo a la tuya

le hubieran acelerado los latidos

de tu corazón

para tener diez años más,

tal vez estaríamos a esta hora

celebrando el encuentro

frente a un par de cervezas en la terraza de un café,

felices de que el azar hubiera tramado

esta cita un soleado mediodía de julio,

hecho a propósito para iniciar

una duradera historia de amor.

Pero nada de esto es lo que sucede ahora

en la que te miro caminar solitaria por la acera

con largo tu pelo color miel que te cae

como una silenciosa catarata por tu espalda

atravesado por la luz y desordenado por el aire,

y en la que tú me miras pasar lentamente

en un autobús y ves una cara

ausente que te observa desde la ventanilla

y que te parece por un momento familiar.

Pero el tiempo tenía otros planes para nosotros

porque el semáforo cambió a verde,

porque sonó una llamada en tu celular,

y la tarde siguió su curso,

tú con tu edad y yo con mi herida.

Ahora ya lo sabemos: 
a veces el destino es el más tirano de los dioses,

y el amor es el más avaro a la hora

de repartir sus poderes.

\section{Mis muertes}

A los dieciséis años

uno de mis mejores amigos del colegio

se pegó un tiro en la cabeza

por una decepción amorosa.

A los treinta y nueve

mi más admirado profesor de literatura

murió de hipotermia en un río,

por salvar a su perro que se ahogaba

bajo una engañosa capa de hielo.

A los cuarenta y cuatro

un poeta norteamericano que acababa

de conocer desapareció para siempre

en una remota isla al sur del Japón

por ver de cerca la boca de un volcán.

Muchos dirán con sangre fría

que la impaciencia del primero,

la extrema confianza del segundo

o el imprudente proceder

del tercero, fueron la causa determinante,

como si su explicación pudiera justificar

los resultados.

A lo largo de la vida

uno va acumulando muertes

y se empieza a pensar sin quererlo

en cuál de esas será la suya, 
si será por amor, Sergio, por lealtad,

Eduardo, o por valentía,

Craig.



